\title{
Basal and 24-h C-peptide and insulin secretion rate in normal man
}

\author{
Y.T. Kruszynska, P. D. Home, I. Hanning and K. G. M. M. Alberti \\ Department of Medicine, University of Newcastle-upon-Tyne, Newcastle-upon-Tyne, UK
}

\begin{abstract}
Summary. An understanding of the metabolic abnormalities rising from inappropriate insulin delivery in diabetic patients demands a knowledge of 24-h and basal insulin secretion rates in normal man. We have used biosynthetic human Cpeptide to determine its kinetic parameters in 10 normal subjects and applied these to measurements of plasma concentrations in the same subjects to determine pancreatic secretion rate. Metabolic clearance rate measured by stepped primed infusion of biosynthetic human C-peptide at rates of 10,19 and $26 \mathrm{nmol} / \mathrm{h}$ was $4.7 \pm 0.7( \pm \mathrm{SD}) \mathrm{ml} \cdot \mathrm{kg}^{-1} \cdot \mathrm{min}^{-1}$, and was independent of infusion rate. Fractional clearance $\left(\mathrm{T}_{1 / 2}, 26 \pm\right.$ $3 \mathrm{~min})$ and distribution volume $(0.178 \pm 0.039 \mathrm{l} / \mathrm{kg})$ were calculated from the decline in concentration after cessation of
\end{abstract}

the highest rate infusion. Basal insulin secretion calculated from the C-peptide metabolic clearance rate and plasma concentrations for the period 02.00 to 07.00 hours was $1.3 \pm$ $0.4 \mathrm{U} / \mathrm{h}$. Over $24 \mathrm{~h}$ total insulin secretion on a standard high carbohydrate diet was $63 \pm 15 \mathrm{U}$, calculated from the area under the C-peptide concentration curve. Basal insulin secretion, therefore, accounted for $50 \pm 8 \%$ of total insulin secretion. Although only $5.6 \pm 1.1 \%$ of C-peptide was detected in $24-\mathrm{h}$ urine collections, urinary $\mathrm{C}$-peptide excretion was significantly related to 24 -h C-peptide secretion $(r=0.74, p<0.02)$.

Key words: C-peptide, insulin secretion, C-peptide pharmacokinetics, insulin dose.
Pancreatic insulin secretion in man cannot be determined from peripheral insulin concentrations and clearance because the liver removes about $50 \%$ of the insulin secreted into the portal vein [1, 2]. Furthermore, insulin kinetics are measurable only under conditions of a glucose clamp, which may itself affect insulin clearance. Since C-peptide is co-secreted from the islet B cell in equimolar amounts with insulin [3] but is not significantly extracted by the liver $[4,5]$, a number of studies have attempted to estimate insulin secretion from peripheral or hepatic venous $C$-peptide concentrations [5-7]. Provided that the kinetics of removal of C-peptide from the circulation are known, insulin secretion rate can be quantitated from peripheral C-peptide concentrations. However, owing to scarcity of human C-peptide, these calculations have had to rely on the C-peptide kinetic data of Faber et al. [8], derived from single dose studies in 6 normal subjects, and validated by a single infusion study. Curve fitting to data obtained after bolus intravenous injection is, however, a somewhat arbitrary and imprecise procedure. Furthermore, subsequent studies have used different assay standards and antisera (a particular problem with C-peptide [9]), and have inevitably been unable to use individualised kinetic data.
The availability of well characterised human C-peptide from recombinant DNA techniques has provided the opportunity to reassess our understanding of C-peptide pharmacokinetics and to attempt to quantitate pancreatic insulin secretion in normal man [10]. As a knowledge of insulin delivery rate in man is necessary to our understanding of insulin requirements by different delivery routes in diabetic man, we have made a modelfree calculation of 24-h and basal secretion rate in normal subjects.

\section{Subjects and methods}

\section{Subjects}

Ten normal volunteers (five male, five female) were recruited, with informed consent in each case, after approval for the study had been given by the local Ethical Committee. The characteristics of the subjects are given in Table 1.

\section{Study protocol}

For measurement of serum C-peptide kinetics, subjects were admitted to the metabolic unit, Freeman Hospital, at 08.00 hours after an overnight fast. Two intravenous cannulae were inserted into forearm veins. One cannula was used for infusion of biosynthetic human C-peptide 
Table 1. Characteristics of the patients studied

\begin{tabular}{lllll}
\hline $\begin{array}{l}\text { Subject } \\
\text { (no.) }\end{array}$ & $\begin{array}{l}\text { Sex } \\
(\mathrm{M} / \mathrm{F})\end{array}$ & $\begin{array}{l}\text { Age } \\
\text { (years) }\end{array}$ & $\begin{array}{l}\text { Weight } \\
(\mathrm{kg})\end{array}$ & $\begin{array}{l}\mathrm{BMI} \\
\left(\mathrm{kg} / \mathrm{m}^{2}\right)\end{array}$ \\
\hline 1 & F & 24 & 68 & 27 \\
2 & $\mathrm{M}$ & 25 & 82 & 25 \\
3 & $\mathrm{M}$ & 20 & 70 & 21 \\
4 & $\mathrm{M}$ & 20 & 93 & 27 \\
5 & $\mathrm{M}$ & 27 & 67 & 21 \\
6 & $\mathrm{~F}$ & 33 & 51 & 19 \\
7 & $\mathrm{~F}$ & 31 & 55 & 22 \\
8 & $\mathrm{~F}$ & 19 & 51 & 21 \\
9 & $\mathrm{M}$ & 32 & 68 & 21 \\
10 & $\mathrm{~F}$ & 27 & 57 & 23 \\
Mean \pm SD & & $26 \pm 5$ & $66 \pm 14$ & $23 \pm 3$ \\
\hline
\end{tabular}

(Novo Research Institute, Bagsvaerd, Denmark), over 99\% pure on high performance liquid chromatography, diluted in Haemaccel (Hoechst, Frankfurt am Main, FRG). The second cannula was used for intermittent blood sampling, being flushed after use with $0.15 \mathrm{~mol} / 1 \mathrm{NaCl}$ in water.

After a 30-min rest, 3 basal blood samples were taken at $15 \mathrm{~min}$ intervals. A stepped primed infusion of C-peptide from a syringe pump was then begun. The prime was given over $10 \mathrm{~min}$ to fill the assumed C-peptide space on the basis of previous reports [8]. Each step was continued for $60 \mathrm{~min}$, with consecutive rates of 10,19 and $26 \mathrm{nmol} / \mathrm{h}$. Actual infusion rate in each subject was, however, determined from the C-peptide concentration actually measured in the infusate. Blood samples for measurement of serum insulin and C-peptide were taken at $+10,+30,+45,+50,+55$ and +60 min during each step. After stopping the highest rate infusion, samples were taken every 5 min for $60 \mathrm{~min}$ and then at $10-\mathrm{min}$ intervals until $90 \mathrm{~min}$ for determination of fractional clearance rate of C-peptide from serum.

For assessment of diurnal insulin secretion, subjects were readmitted to the metabolic unit, Freeman Hospital, 1 week after the infusion study. They were admitted at $\mathbf{1 7 . 0 0}$ hours after a light lunch. An intravenous cannula was inserted into an antecubital vein, and blood samples were taken from 18.00 hours for $24 \mathrm{~h}$ while on a standard $2020-\mathrm{kcal}$ diet distributed between breakfast $(450 \mathrm{kcal})$, lunch $(670 \mathrm{kcal})$ and dinner $(600 \mathrm{kcal})$ plus a milk allowance. As snacks subjects were allowed unsweetened tea or coffee only $2 \mathrm{~h}$ after the main meals. The composition of the diet as a percentage of total energy was $56 \%$ carbohydrate, $29 \%$ fat and $15 \%$ protein. Blood samples for Cpeptide and insulin estimation were taken at 15-min intervals for $1 \mathrm{~h}$ after each of the 3 main meals, at $30-\mathrm{min}$ intervals for the subsequent $2 \mathrm{~h}$ and then hourly. A 24-h urine collection was obtained on this day.

\section{Sample collection and analytical techniques}

Blood samples for insulin and C-peptide were allowed to clot at room temperature $(30 \mathrm{~min})$ and serum stored at $-40^{\circ} \mathrm{C}[11]$ until assayed. Serum insulin was assayed by a double antibody technique [12]. Cpeptide was measured in serum samples after extraction of proinsulin with Sepharose bound anti-insulin antibodies [13]. C-peptide was measured by ethanol precipitation radioimmunoassay [13] using the M1230 antibody and a synthetic standard (Novo Research Institute, Bagsvaerd, Denmark). The latter was found to cross-react in the assay with the biosynthetic human C-peptide with a parallel and overlapping curve. Interassay coefficients of variation were $3.5 \%$ at $0.16 \mathrm{nmol} / 1$ and $3.5 \%$ at $1.03 \mathrm{nmol} / \mathrm{l}$. All samples from a single individual from both study days were, however, assayed together.

\section{Mathematical analysis}

C-peptide concentrations during the infusion study were corrected for continuing pancreatic C-peptide delivery. The endogenous C-peptide concentration was estimated by multiplying the basal C-peptide/insulin ratio by the serum insulin concentration in each subject. The result was then subtracted from the measured serum C-peptide concentration. This was considered valid as the subjects remained in basal state throughout the infusion study, and any changes in insulin secretion were much slower than fractional clearance rates of either insulin or C-peptide.

Metabolic clearance rate (MCR) for C-peptidè was calculated from the formula $\mathrm{MCR}=$ (infusion rate of C-peptide) $/$ (concentration of C-peptide in serum), using the mean of the corrected C-peptide concentrations between 45 and $60 \mathrm{~min}$ for each step.

For determination of the fractional clearance rate of C-peptide from serum $(\mathrm{k})$, a single exponential was fitted to the corrected C-peptide concentrations from 5 to $50 \mathrm{~min}$ after stopping the highest rate infusion. No attempt was made to estimate kinetic parameters to represent mixing during the first $5 \mathrm{~min}$ after stopping the infusion, such procedures depending on sampling site and being of questionable validity. Serum half time was calculated as $T_{1 / 2}=0.693 / \mathrm{k}$. Volume of distribution was $\left(V_{D}\right)=M C R / k$.

Secretion rates of $\mathrm{C}$-peptide and hence insulin were calculated by multiplying the area under the $24-\mathrm{h}$ C-peptide concentration curve by the MCR for that individual. For estimation of basal secretion rates a mean C-peptide concentration was calculated for the interval 02.00 to 07.00 hours of the $24-\mathrm{h}$ profile for each individual. Concentrations were constant over this time interval (see Results). Conversion of molar secretion rates to units of insulin assumed a molecular weight of 5808 for human insulin and a potency of $28.9 \mathrm{U} / \mathrm{mg}$ for anhydrous salt free human insulin [14].

It should be noted that the kinetic parameters $k$ and $V_{D}$ were not used in calculation of secretion rates. The results are therefore independent of any assumptions necessary for compartmental analysis.

\section{Statistical analysis}

Results are stated as mean \pm SD unless otherwise indicated. Correlation was sought by the least squares method. The areas under the serum insulin and $\mathrm{C}$-peptide concentration curves were calculated using the trapezoidal rule. Significance of differences was assessed using Student's paired t-test. A $p$ value of $<0.05$ was considered statistically significant.

\section{Results}

\section{Kinetic parameters}

During the infusion of biosynthetic human C-peptide, steady state serum C-peptide concentrations were achieved by $30 \mathrm{~min}$ of each step (Fig. 1), and the concentrations achieved covered the physiological diurnal range of C-peptide concentrations. Metabolic clearance rate (MCR) of C-peptide calculated from the steady state serum C-peptide concentrations achieved during the infusion study showed no evidence of saturation with increasing C-peptide concentrations within the range studied $(4.8 \pm 1.0,4.8 \pm 0.7$ and $4.6 \pm 0.7 \mathrm{ml}$. $\mathrm{kg}^{-1} \cdot \min ^{-1}$ at infusion rates of 10,19 and $26 \mathrm{nmol} / \mathrm{h}$ respectively). For each subject, therefore, MCR was averaged for the three infusion steps. C-peptide MCR in these 10 subjects was then $4.7 \pm 0.7 \mathrm{ml} \cdot \mathrm{kg}^{-1} \cdot \mathrm{min}^{-1}$; individual data are presented in Table 2. C-peptide MCR was negatively related to body weight $(r=-0.66, p<$ $0.05)$ and to BMI ( $r=-0.80, p<0.01)$, but not to ideal body weight (corrected to BMI males 22.0 , females 20.8 [15]). Differences in MCR between subjects could ac- 
Table 2. Kinetic parameters of C-peptide in man, and areas under physiological 24-h serum insulin and C-peptide concentration curves

\begin{tabular}{|c|c|c|c|c|c|}
\hline $\begin{array}{l}\text { Subject } \\
\text { (no.) }\end{array}$ & $\begin{array}{l}\text { Metabolic } \\
\text { clearance rate } \\
\left(\mathrm{ml} \cdot \mathrm{kg}^{-1} \cdot \mathrm{min}^{-1}\right)\end{array}$ & $\begin{array}{l}\text { Serum } \\
\text { half time } \\
\text { (min) }\end{array}$ & $\begin{array}{l}\text { Volume of } \\
\text { distribution } \\
(\mathrm{ml} / \mathrm{kg})\end{array}$ & $\begin{array}{l}\text { Area under insulin } \\
\text { concentration curve } \\
\left(\mathrm{mU} \cdot \mathrm{l}^{-1} \cdot \mathrm{h}\right)\end{array}$ & $\begin{array}{l}\text { Area under C-peptide } \\
\text { concentration curve } \\
\left(\text { nmol } \cdot l^{\cdots 1} \cdot h\right)\end{array}$ \\
\hline 2 & 4.29 & 25.7 & 159 & 445 & 23.1 \\
\hline 3 & 4.36 & 27.3 & 172 & 383 & 18.3 \\
\hline 4 & 3.79 & $-{ }^{a}$ & $-a^{a}$ & 623 & 25.9 \\
\hline 5 & 5.87 & 29.2 & 247 & 212 & 10.3 \\
\hline 8 & 5.20 & 30.0 & 225 & 537 & 25.3 \\
\hline 9 & 4.52 & 24.9 & 163 & 449 & 20.4 \\
\hline 10 & 4.88 & 26.4 & 186 & 436 & 23.2 \\
\hline Mean \pm SD & $4.7 \pm 0.7$ & $25.5 \pm 3.1$ & $178 \pm 39$ & $403 \pm 124$ & $20.8 \pm 4.4$ \\
\hline
\end{tabular}

a Result unavailable due to venous sampling problems

Table 3. Insulin and C-peptide secretion rates and urinary C-peptide excretion rate in normal man

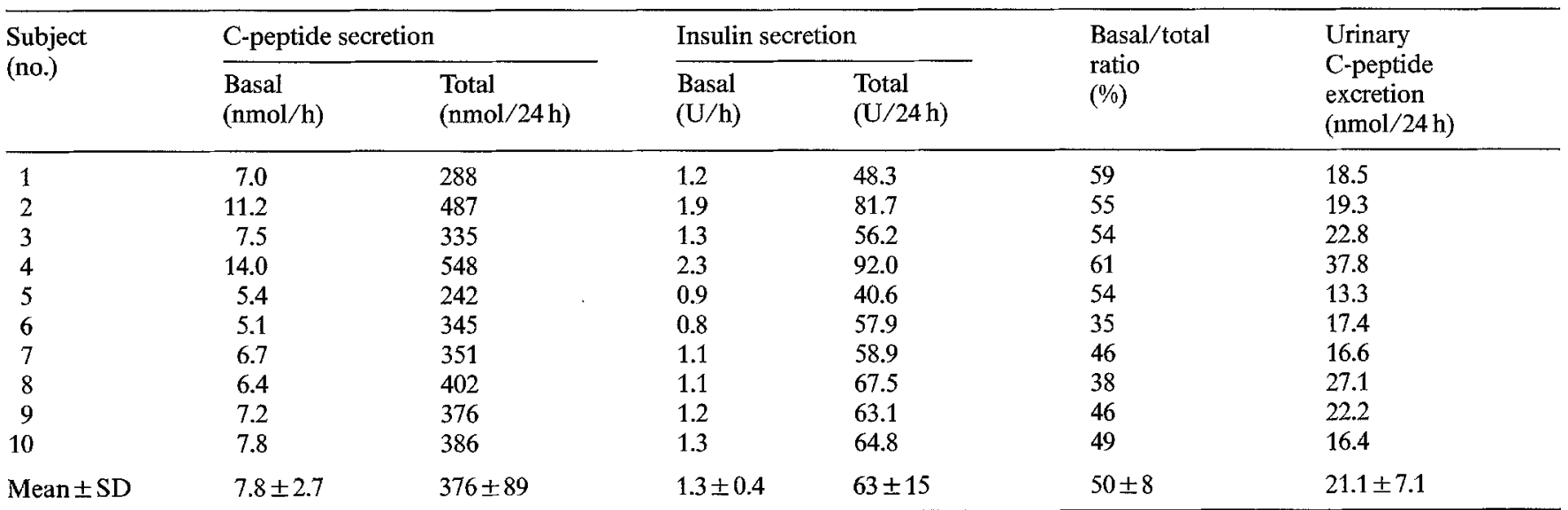

Conversion of C-peptide secretion rate to units of insulin assumes a molecular weight for human insulin of 5808 and a potency of $28.9 \mathrm{U} / \mathrm{mg}$

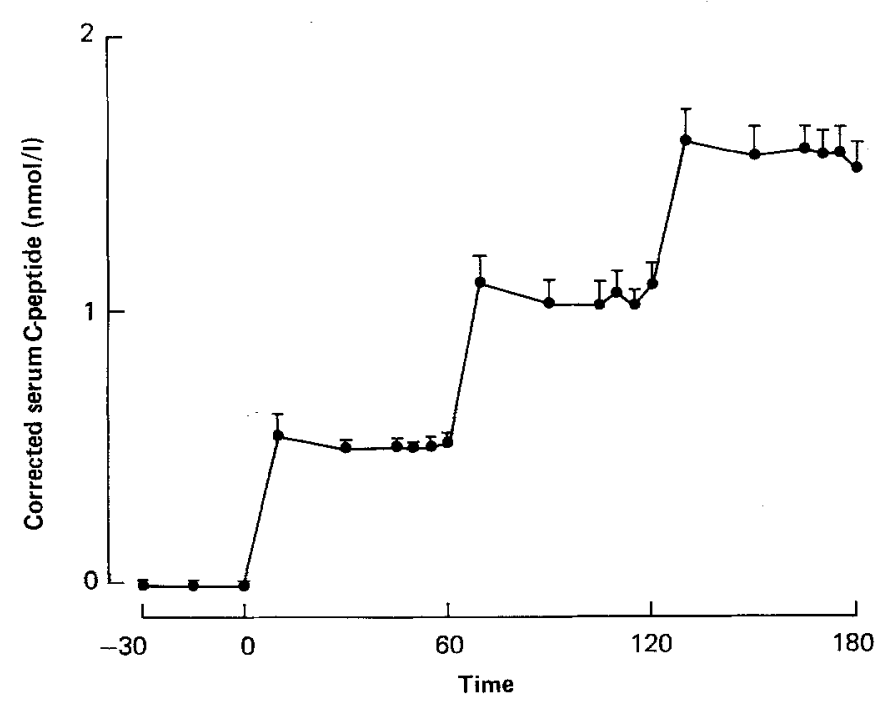

Fig. 1. Serum C-peptide concentration corrected for endogenous Cpeptide secretion in 10 normal subjects during stepped primed infusion of biosynthetic human C-peptide at consecutive rates of 10,19 and $26 \mathrm{nmol} / \mathrm{h}$ count for $68 \%$ of the differences in basal C-peptide concentration $(r=0.82, p<0.005)$.

Fractional clearance rate of C-peptide from serum was $0.028 \pm 0.003 \mathrm{~min}^{-1}$, corresponding to a serum half time $\left(\mathrm{T}_{1 / 2}\right)$ of $26 \pm 3 \mathrm{~min}$. The apparent distribution volume in these subjects was $0.178 \pm 0.0391 / \mathrm{kg}(11.1 \pm$ 2.61).

\section{C-peptide and insulin secretion rates}

The 24-h profiles of serum C-peptide and insulin in the normal subjects on the standard high carbohydrate diet are shown in Figure 2. During the night between 02.00 and 07.00 hours serum insulin and C-peptide concentrations remained constant in all individuals, allowing calculation of basal secretion rates. Basal and 24-h Cpeptide secretion rates calculated from the 24-h C-peptide concentration curves and the MCR for each individual are given in Table 3. In these subjects 24-h secretion of C-peptide (and therefore insulin) was $376 \pm 89 \mathrm{nmol}$. Basal secretion rate during the night was 


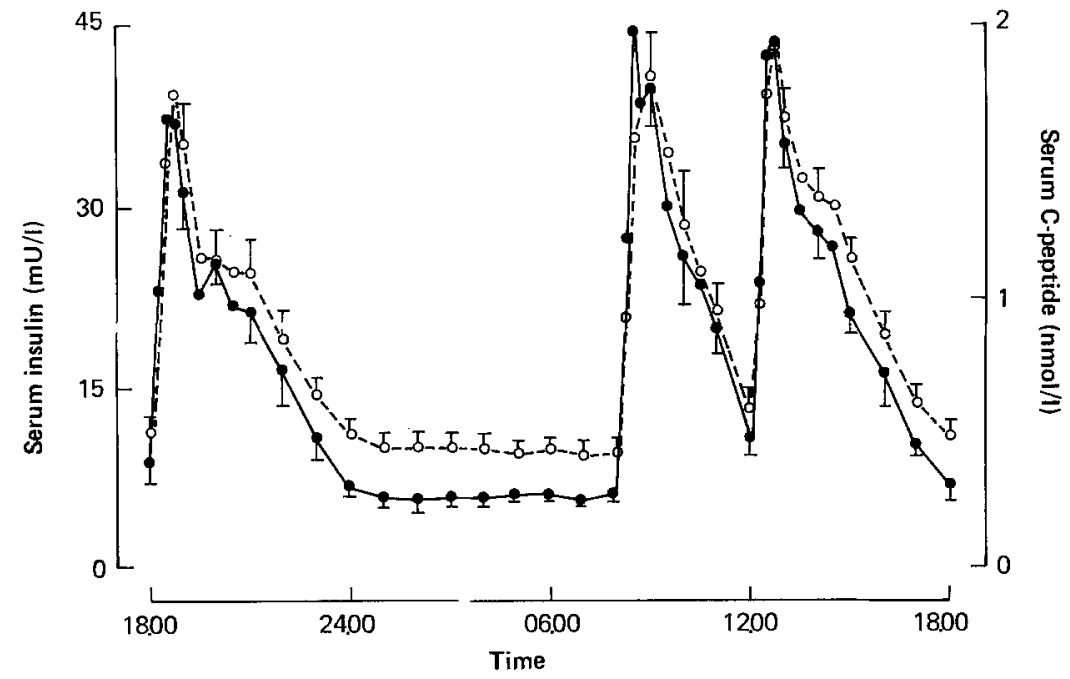

Fig. 2. 24-h profiles of serum insulin $(-O)$ and $\mathrm{C}$ peptide $(\mathrm{O}---\mathrm{O})$ in 10 normal subjects on the standard high carbohydrate diet
$7.8 \pm 2.7 \mathrm{nmol} / \mathrm{h}$. These figures correspond to a daily insulin secretion of $63 \pm 15 \mathrm{U} / 24 \mathrm{~h}$ and a basal secretion of $1.3 \pm 0.4 \mathrm{U} / \mathrm{h}$. Basal C-peptide and hence insulin secretion expressed over $24 \mathrm{~h}$ was thus $50 \pm 8 \%$ of total daily delivery. The ratio area under the "basal" insulin concentration curve to area under the 24 -h concentration curve was, however, only $36 \pm 11 \%(p<0.001 \mathrm{com}-$ pared to C-peptide).

Basal insulin secretion rate was related to body weight $(r=0.87, p<0.002)$ and to BMI $(r=0.74, p<$ 0.02 ). After correction to ideal body weight (BMI males 22.0 , females 20.8 [15]), this relationship no longer held. Total 24-h secretion rates could not be related to weight or BMI.

\section{Urinary C-peptide excretion}

Urinary C-peptide excretion was $21.1 \pm 7.1 \mathrm{nmol} / 24 \mathrm{~h}$ (Table 3), 5.6 $\pm 1.1 \%$ (range $4.0-6.9 \%$ ) of calculated pancreatic secretion. Excretion correlated $(r=0.75, p<$ 0.02 ) with secretion rate, and therefore the product of average $\mathrm{C}$-peptide concentration and MCR.

\section{Discussion}

The study described in the present paper calculates basal and 24-h insulin secretion from the product of C-peptide metabolic clearance rate and the integrated area under the C-peptide concentration curve. Such an approach makes none of the assumptions inherent in compartmental analysis [8], and is not dependent on serum insulin:C-peptide ratios at individual time points [16]. It has recently been validated in the dog [17], and is not applicable to minute to minute calculation of changing secretion rates when compartmental analysis must be used.

Nevertheless, a number of assumptions underlie the method. Clearly it is important that C-peptide clearance does not vary during the day, for example with meals or during sleep. Biosynthetic and native C-peptide must be handled identically within the circulation, even though delivered into different sites (peripheral and portal veins). In particular, hepatic extraction of C-peptide must be low [4, 5]. Measurement of biosynthetic C-peptide in the infusate and in serum must be equivalent, and the measurement of native C-peptide accurate as well as precise for calculation of secretion rates. Precautions must be taken against degradation in freezers nominally operating at $-20^{\circ} \mathrm{C}$ [11]. A particular problem might be anticipated from assay cross-reaction with proinsulin and its derivatives, as many C-peptide antibodies show high cross-reactivity for these substances [18]. Though we extracted proinsulin/derivatives with insulin antibody bound to Sepharose, this may be a council of perfection with the M1230 antibody, which only has $11 \%$ crossreactivity for proinsulin preparations [18]. In converting integrated C-peptide secretion rates to insulin, the unit potency of insulin should be taken as the purest preparations, after allowance for salt and water [14].

The C-peptide MCR calculated here was similar to that obtained by curve fitting after bolus injection of small amounts of synthetic C-peptide [8], though somewhat higher than estimates from similar studies using a different source of biosynthetic C-peptide [10]. This discrepancy is puzzling, as measurement of MCR ought to be relatively independent of assay and assay standards, and our figure $\left(4.7 \pm 0.7 \mathrm{ml} \cdot \mathrm{kg}^{-1} \cdot \mathrm{min}^{-1}\right)$ would be even higher $\left(5.0 \mathrm{ml} \cdot \mathrm{kg}^{-1} \cdot \mathrm{min}^{-1}\right)$ if correction was made for the relationship with BMI. The calculated $\operatorname{MCR}(305 \pm 47 \mathrm{ml} / \mathrm{min})$ is well in excess of glomerular filtration rate. As removal of C-peptide by the kidney is high [19], it seems likely that other renal mechanisms must be involved. The small amount of C-peptide secreted that appears in the urine $(5.6 \pm 1.1 \%)$ does not contradict this, as the luminal borders of the proximal tubules have high peptidase activity [20]. 
We intentionally avoided fitting curves to the early (mixing) phase of the concentration decay curve after cessation of the high rate infusion, but our fractional clearance rate $\left(0.028 \pm 0.003 \mathrm{~min}^{-1}, \mathrm{~T}_{1 / 2} 26 \pm 3 \mathrm{~min}\right)$ is similar to previous estimates $[8,10]$. The volume of distribution is then consistent with extracellular fluid volume. Examination of the decay curves did, however, suggest the likelihood of a further exponential (apparent after $60 \mathrm{~min}$ ) in some subjects. C-peptide concentrations at this time approach basal concentrations, however, and curve fitting would be very imprecise after correction for continuing endogenous secretion.

Basal insulin delivery rate was calculated from overnight C-peptide concentrations, enabling stability of secretion to be confirmed, and avoiding the stresses inherent in having subjects be present for study at the beginning of the morning. Converted to units of insulin this represents $1.3 \pm 0.4(\mathrm{SD}) \mathrm{U} / \mathrm{h}$, representing very little difference from the basal infusion rates we have found appropriate for continuous subcutaneous insulin infusion in C-peptide negative patients [21]. This result would also be compatible with our measured fasting insulin concentrations, first pass hepatic removal of $65 \%$ of insulin secreted, and an insulin MCR of $1.251 / \mathrm{min}$ for insulin delivery into the systemic circulation [22]. Faber et al. [8] present data which would give somewhat lower results, mainly because morning fasting C-peptide concentrations were markedly lower than the stable overnight levels we find. Comparison with the results of Polonsky et al. [10] is complicated by the absence of fasting C-peptide concentration data in their paper. Basal insulin secretion was related to both weight and BMI. Unfortunately, these variables were themselves highly correlated, invalidating separation of their effects by multiple regression analysis.

The other major method for estimating insulin production rate is the hepatic venous cannula technique, a procedure dependent on representative sampling of hepatic venous blood and accurate measurement of hepatic plasma flow $[5,23]$. These authors estimate rather lower basal insulin production rates at around $1.0 \mathrm{U} / \mathrm{h}$, but this discrepancy disappears entirely if their data is recalculated using the true potency of insulin (28.9 rather than $24 \mathrm{U} / \mathrm{mg}$ [14]), and our heaviest (and overweight) subject is excluded.

Total daily insulin secretion was $63 \pm 15 \mathrm{U}$, or $60 \mathrm{U} /$ day if corrected to normal BMI by regression analysis. From a separate study of $54 \mathrm{C}$-peptide negative patients we selected the closest match for sex, age and BMI. Their daily insulin dose requirement was $55 \pm$ $20 \mathrm{U} /$ day, again consistent with previous injection data [24]. If anything, dose requirements in this type of patient fall with intensification of therapy using infusion pumps [25].

As insulin-dependent patients, even after a period of good metabolic control, have decreased peripheral tissue sensitivity to insulin [25], we suspect that peripheral insulin delivery in diabetes is causing a counterbalanc- ing reduction in insulin requirement, as predicted by rat islet transplant studies [26, 27].

It is notable that the ratio of the areas under the basal and prandial parts of the C-peptide and insulin concentration curves are different. It is a further assumption of our methodology that MCR for C-peptide is not different in fed and postabsorptive states. This implies that the insulin metabolic clearance rate is higher in the fasting than fed states, consistent with data suggesting that hepatic insulin extraction decreases with increasing portal vein insulin concentration [28]. The result is, however, contrary to direct studies by hepatic venous sampling [5, 23], where calculated hepatic extraction of insulin does not change with increased plasma flow and insulin secretion. These calculations depend, however, on taking a ratio of two variables (splanchnic insulin and C-peptide production) that are themselves derived from subtraction of measured concentration. The results are therefore not very precise.

Acknowledgements. We thank Dr. I. Jensen and Dr. L. Heding (Novo Research Institute) for the supply of biosynthetic C-peptide and Sepharose bound insulin antibody. The study was supported by the Wellcome Trust, the Medical Research Council, and the British Diabetic Association.

\section{References}

1. Blackard WG, Nelson NC (1970) Portal and peripheral vein immunoreactive insulin concentrations before and after glucose infusion. Diabetes 19:302-306

2. Jaspan JB, Polonsky K (1982) Glucose ingestion in dogs alters the hepatic extraction of insulin: in vivo evidence for a relationship between biologic action and extraction of insulin. J Clin Invest 69 : $516-525$

3. Rubenstein AH, Clark JL, Melani F, Steiner DF (1969) Secretion of proinsulin C-peptide by pancreatic beta cells and its circulation in blood. Nature (Lond) 224: 697-699

4. Polonsky K, Jaspan JB, Pugh W, Cohen D, Schneider M, Schwartz T, Moossa AR, Tager H, Rubenstein AH (1983) Metabolism of C-peptide in the dog. In vivo demonstration of the absence of hepatic extraction. J Clin Invest 72: 1114-1123

5. Waldhausl W, Bratusch-Marrain P, Gasic S, Korn A, Nowotny P (1979) Insulin production rate following glucose ingestion estimated by splanchnic C-peptide output in normal man. Diabetologia 17:221-227

6. Eaton RP, Allen RC, Schade DS, Erickson KM, Standefer J (1980) Prehepatic insulin production in man: kinetic analysis using peripheral connecting peptide behaviour. J Clin Endocrinol Metab 51: $520-528$

7. Meistas MT, Zadik Z, Margolis S, Kowarski AA (1981) Correlations of urinary excretion of C-peptide with the integrated concentration and secretion rate of insulin. Diabetes 30:639-643

8. Faber OK, Hagen C, Binder C, Markussen J, Naithani VK, Blix PM, Kuzuya H, Horwitz DL, Rubenstein AH, Rossing N (1978) Kinetics of human connecting peptide in normal and diabetic subjects. J Clin Invest 62: 197-203

9. Caygill CPJ, Gaines Das RE, Bomgham DR (1980) Use of a common standard for comparison of insulin C-peptide measurements by different laboratories. Diabetologia 18: 197-204

10. Polonsky KS, Licinio-Paixao J, Given BD, Pugh W, Rue P, Galloway J, Karrison T, Frank B (1986) Use of biosynthetic human Cpeptide in the measurement of insulin secretion rates in normal volunteers and type 1 diabetic patients. J Clin Invest 77: 98-105 
11. Bonser AM, Garcia-Webb P (1984) C-peptide measurement: methods and clinical utility. CRC Crit Rev Clin Lab Sci 19: 297-352

12. Soeldner JS, Sloane D (1965) Critical variables in the radioimmunoassay of serum insulin using the double-antibody technique. Diabetes 14: 771-779

13. Heding LG (1975) Radioimmunological determination of human C-peptide in serum. Diabetologia 11: 541-548

14. Pingel M, Vølund A, Sørensen E, Sørensen AR (1982) Assessment of insulin potency by chemical and biological methods. In: Gueriguian JL, Bransome ED, Outschoorn AS (eds) Hormone drugs. United States Pharmacopeial Convention, Inc, Rockville, pp 200-207

15. Royal College of Physicians of London (1983) Obesity. A report of the Royal College of Physicians. J R Coll Physicians Lond 17: 5-65

16. Polonsky K, Rubenstein AH (1984) C-peptide as a measure of the secretion and hepatic extraction of insulin: pitfalls and limitations. Diabetes 33: 486-494

17. Polonsky K, Frank B, Pugh W, Addis A, Karrison T, Meier P, Tager H, Rubenstein A (1986) The limitations to and valid use of C-peptide as a marker of the secretion of insulin. Diabetes 35 : 379-386

18. Faber OK, Binder C, Markussen J, Heding LG, Naithani VK, Kuzuya H, Blix PM, Horwitz DL, Rubenstein AH (1978) Characterisation of seven C-peptide antisera. Diabetes 27 [Suppl 1]: 70-77

19. Katz AI, Rubenstein AH (1973) Metabolism of proinsulin, insulin and C-peptide in the rat. J Clin Invest 52: 1113-1121

20. Kenny AJ, Maroux S (1982) Topology of microvillar membrane hydrolases of kidney and intestine. Physiol Rev 62: 91-128

21. Home PD, Capaldo B, Burrin JM, Worth R, Alberti KGMM (1982) A crossover comparison of continuous subcutaneous insulin infusion (CSII) against multiple insulin injections in insulindependent diabetic subjects: improved control with CSII. Diabetes Care 5: 466-471

22. Home PD, Massi-Benedetti M, Shepherd GAA, Hanning I, Alberti KGMM, Owens DR (1982) A comparison of the activity and disposal of semi-synthetic human insulin and porcine insulin in normal man by the glucose clamp technique. Diabetologia 22 : 41-45

23. Waldhaus1 W, Bratusch-Marrain P, Gastic S, Korn A, Nowotny P (1982) Insulin production rate, hepatic insulin retention and splanchnic carbohydrate metabolism after oral glucose ingestion in hyperinsulinaemic type 2 . (non-insulin-dependent) diabetes mellitus. Diabetologia 23:6-15

24. Home PD, Mann NP, Hutchison AS, Park R, Walford S, Murphy M, Reeves WG (1984) A fifteen-month double-blind cross-over study of the efficacy and antigenicity of human and pork insulins. Diabetic Med 1: 93-98

25. Yki Jarvinen H, Koivisto V (1984) Continuous subcutaneous insulin infusion therapy decreases insulin resistance in type 1 diabetes. J Clin Endocrinol Metab 58: 659-666

26. Kruszynska YT, Home PD, Alberti KGMM (1985) Comparison of portal and peripheral insulin delivery on carbohydrate metabolism in streptozotocin diabetic rats. Diabetologia 28: 167-171

27. Kruszynska YT, Home PD, Agius L, Alberti KGMM (1986) Hepatic glycogen metabolism and insulin receptor status after long term peripheral insulin delivery in the islet transplanted diabetic rat. Diabetes 35: 306-310

28. Harding PE, Bloom G, Field JB (1975) Effect of infusion of insulin into portal vein on hepatic extraction of insulin in anaesthetised dogs. Am J Physiol 228: 1580-1588

Received: 4 August 1986

and in revised form: 13 November 1986

Dr. Y.T. Kruszynska

Department of Medicine

Medical School

Framlington Place

Newcastle-upon-Tyne NE2 4HH

UK 